\title{
Infections in British clinical laboratories, 1988-1989
}

\author{
N R Grist, J A N Emslie
}

\begin{abstract}
During 1988-89 this continuing survey showed 18 infections in the staff of laboratories reporting from 166 centres, representing 21756 person-years of exposure. Shigella and other bowel infections (one caused by $S$ typhi) predominated, affecting 11 microbiology medical laboratory scientific officers. Three shigella infections originated from quality control samples. Pulmonary tuberculosis affected four workers, including two mortuary technicians, but without detected occupational exposure to Mycobacterium tuberculosis. Other infections included one caused by Brucella melitensis. Hepatitis was not reported.

The sustained low level of hepatitis is encouraging and suggests a low risk to staff of bloodborne infections such as human immunodeficiency virus.
\end{abstract}

\section{Methods}

The survey, completing the second decade of the ongoing programme, was conducted by the same methods as reported previously. ${ }^{1}$ Questionnaires were sent to members of the Association of Clinical Pathologists (ACP), to non-members who belonged to the British Association in Forensic Medicine (BAFM), and to a supplementary list compiled with the help of the Institute of Medical Laboratory Sciences (IMLS). To conform with reorganisation of the surveillance systems of the Communicable Diseases (Scotland) Unit (CDSU), data were compiled using a Compaq 386 Personal Computer running DataEase (Sapphire) 4.01 software.

\section{Results}

Returns were received from 166 centres comprising 139 in England, 21 in Scotland, four in Wales and two in Northern Ireland. Of these, 127 were from ACP respondents, one of them including a Blood Transfusion Centre, 33 from the IMLS list including two Blood Transfusion Centres, and six from BAFM members.

\section{INCIDENCE OF INFECTIONS}

Table 1 summarises the overall data, including all reported infections, irrespective of whether they were suspected to be of occupational origin. Infections were reported from 16 laboratory centres (14 in England, including the Channel Islands, two in Scotland). They comprised 18 cases of which two cases were reported from each of two laboratories in England. As before, most $(n=11)$ were bacterial bowel infections, predominantly shigellosis but including one

Table 1 Reported infections (No/100 000 person-years)

The University of
Glasgow and the
Communicable
Diseases (Scotland)
Unit, Ruchill Hospital,
Glasgow G20 9NB
N R Grist
J A N Emslie
Correspondence to:
Dr N R Grist
Accepted for publication
25 March 1991

The University of Communicable Glasgow G20 9NB N R Grist J A N Emslie

Correspondence to: 25 March 1991

\begin{tabular}{|c|c|c|c|c|c|}
\hline Grade and discipline & $\begin{array}{l}\text { Population at risk } \\
\text { (person-years) }\end{array}$ & Salmonella & Tuberculosis & Shigella & Others \\
\hline $\begin{array}{l}\text { Medical: } \\
\text { Morbid anatomy } \\
\text { Haematology } \\
\text { Biochemistry } \\
\text { Microbiology } \\
\text { Immunology } \\
\text { Other }\end{array}$ & $\begin{array}{r}2224 \\
872 \\
554 \\
189 \\
507 \\
40 \\
63\end{array}$ & $\begin{array}{l}0 \\
0 \\
0 \\
0 \\
0 \\
0\end{array}$ & $\begin{array}{l}0 \\
0 \\
0 \\
0 \\
0 \\
0\end{array}$ & $\begin{array}{l}0 \\
0 \\
0 \\
0 \\
0 \\
0\end{array}$ & $\begin{array}{l}1(45) \\
1(115) \\
0 \\
0 \\
0 \\
0 \\
0\end{array}$ \\
\hline $\begin{array}{l}\text { Science: } \\
\text { Morbid anatomy } \\
\text { Haematology } \\
\text { Biochemistry } \\
\text { Microbiology } \\
\text { Immunology } \\
\text { Other }\end{array}$ & $\begin{array}{r}974 \\
71 \\
84 \\
551 \\
137 \\
32 \\
99\end{array}$ & $\begin{array}{l}0 \\
0 \\
0 \\
0 \\
0 \\
0\end{array}$ & $\begin{array}{l}0 \\
0 \\
0 \\
0 \\
0 \\
0\end{array}$ & $\begin{array}{l}0 \\
0 \\
0 \\
0 \\
0 \\
0\end{array}$ & $\begin{array}{l}0 \\
0 \\
0 \\
0 \\
0 \\
0\end{array}$ \\
\hline $\begin{array}{l}\text { MLSO: } \\
\text { Morbid anatomy } \\
\text { Haematology } \\
\text { Biochemistry } \\
\text { Microbiology } \\
\text { Immunology } \\
\text { Other }\end{array}$ & $\begin{array}{r}12427 \\
2076 \\
3594 \\
2693 \\
3646 \\
266 \\
153\end{array}$ & $\begin{array}{l}3(24) \\
0 \\
0 \\
0 \\
3(82) \\
0 \\
0\end{array}$ & $\begin{array}{l}2(16) \\
0 \\
1(28) \\
0 \\
1(27) \\
0 \\
0\end{array}$ & $\begin{array}{l}7(56) \\
0 \\
0 \\
0 \\
7(192) \\
0 \\
0\end{array}$ & $\begin{array}{l}2(16) \\
0 \\
0 \\
0 \\
2(55) \\
0 \\
0\end{array}$ \\
\hline $\begin{array}{l}\text { Others } \\
\text { Post mortem mortuary technicians } \\
\text { Post mortem attendants } \\
\text { Nurses, etc } \\
\text { Laboratory assistants } \\
\text { Domestics, etc } \\
\text { Office administrators } \\
\text { Others }\end{array}$ & $\begin{array}{r}6131 \\
487 \\
36 \\
1161 \\
1079 \\
282 \\
481 \\
2419\end{array}$ & $\begin{array}{l}0 \\
0 \\
0 \\
0 \\
0 \\
0 \\
0\end{array}$ & $\begin{array}{l}2(33) \\
2(411) \\
0 \\
0 \\
0 \\
0 \\
0 \\
0\end{array}$ & $\begin{array}{l}0 \\
0 \\
0 \\
0 \\
0 \\
0 \\
0\end{array}$ & $\begin{array}{l}1(16) \\
0 \\
0 \\
0 \\
0 \\
0 \\
0 \\
1(41)\end{array}$ \\
\hline Total (all groups) & 21756 & $3(13 \cdot 7)$ & $4(18 \cdot 4)$ & $7(32 \cdot 2)$ & $4(18 \cdot 38)$ \\
\hline
\end{tabular}


Table 2 Cases of Shigella infection

\begin{tabular}{lcllll}
\hline Infecting organism & Year & Grade & Main discipline & Age & Sex \\
\hline Shigella flexneri & 1988 & MLSO & Microbiology & 23 & Male \\
Shigella flexneri & 1989 & MLSO & Microbiology & 27 & Female \\
Shigella sonnei & 1988 & MLSO & Microbiology & 26 & Female \\
Shigella sonnei & 1989 & MLSO & Microbiology & 30 & Male \\
Shigella sonnei & 1989 & MLSO & Microbiology & 30 & Female \\
Shigella boydii & 1989 & MLSO & Microbiology & 28 & Female \\
Shigella boydii & 1989 & MLSO & Microbiology & $?$ & Male \\
\hline
\end{tabular}

^Attributed to quality control specimens; both $S$ boydii cases in the same laboratory.

Table 3 Cases of Salmonella infection

\begin{tabular}{llllll}
\hline Infecting organism & Year & Grade & Main discipline & Age & Sex \\
\hline S typhi & 1989 & MLSO & Microbiology & 36 & Female \\
Styphimurium & 1988 & MLSO & Microbiology & 49 & Male \\
S braenderup & 1988 & MLSO & Microbiology & 58 & Male \\
\hline
\end{tabular}

typhoid infection. There were four cases of tuberculosis, but none of hepatitis, and fatalities were not reported.

Shigellosis (table 2)

Three infections were acquired during routine diagnostic work with stool specimens. One was acquired during routine subculture and typing of an isolate ( $S$ flexneri) referred from another laboratory, and three others during work with quality control samples. The two $S$ boydii infections were in the same laboratory and the organisms proved identical with the quality control sample by two typing methods. Laboratory accidents were not recognised in these seven cases.

\section{Salmonellosis (table 3)}

The $S$ typhi infection was acquired during routine work with a suspect clinical isolate which later proved to belong to the same phage type. The other two salmonella infections occurred during routine diagnostic work with stool specimens. Associated laboratory accidents were not reported, but the worker who processed the infected $S$ typhi isolated had been ungloved.

\section{Tuberculosis (table 4)}

Exposure to tuberculosis infection was not traced in any of the four reported cases. All seemed to be new infections with pulmonary lesions visible on $x$-ray picture. The haematology worker had last worked with tuberculous material 23 years previously in the microbiology department. The $M$ tuberculosis isolated from her was fully sensitive to antibotics.

The infection in the male mortuary tech-

Table 4 Cases of tuberculosis infection

\begin{tabular}{llllll}
\hline Infecting organism & Year & Grade & Main discipline & Age & Sex \\
\hline M tuberculosis & 1989 & MLSO & Haematology & 49 & Female \\
M tuberculosis & 1989 & Mortuary technician & Morbid anatomy & 46 & Male \\
M tuberculosis & 1988 & MLSO & Microbiology & 28 & Male \\
M tuberculosis & 1988 & Mortuary technician & Morbid anatomy & 32 & Female \\
\hline
\end{tabular}

ॠNot bacteriologically confirmed. nican was detected on routine chest $\mathrm{x}$-ray picture; he had a fully sensitive strain of $M$ tuberculosis on sputum culture. Tuberculosis cases had not been dealt with knowingly in the post mortem room during the previous five years and a review of reported cases and of contacts failed to uncover any such case. As a part-time porter he collected bagged pots of sputum from wards but did not handle infected material until it had been autoclaved.

The microbiologist also yielded $M$ tuberculosis. His source of infection was not found, but the laboratory performs a wide range of microbiological tests including sensitivity tests of strains of $M$ tuberculosis.

The female mortuary technician did not yield $M$ tuberculosis on culture of a bronchial lavage specimen but had a characteristic radiological upper lobe lesion of lung. A definite source of infection was not found but routine post mortem work was the suspected source.

\section{Other infections (table 5)}

A histopathologist without recognised injury at post mortem or surgical cut-up developed paronychia with lymphangitis of the arm which responded to antibiotics and local surgery. Klebsiella and $E$ coli were isolated, suggesting a faecal origin.

A routine microbiology worker without recognised accidental exposure developed enteritis from which an atypical, non-lactose fermenting, lysine decarboxylase negative strain of $E$ coli was isolated-not necessarily of occupational origin.

A receptionist's eye became infected with a Staphylococcus following an accident when a jet of transport medium from a batch of faulty swabs with pin-holes in the caps squirted into her eye.

An MLSO doing routine blood culture work became infected by Brucella melitensis. As the possibility of Brucella infection had not been indicated on the request form which accompanied the clinical specimen, the diagnostic work was carried out by conventional methods and not at containment level 3 . Neither faulty procedure nor an accident was recognised.

\section{Discussion}

Compared with 1986-1987, reports were received from fewer laboratories and covered fewer person-years of exposure. Table 6 shows that the average number of personyears per reporting laboratory had been relatively stable over the decade and did not show a trend towards fewer but larger laboratories participating in the survey. Nevertheless, the incidence rates per 100000 person-years remain valid for comparison with previous years.

Bacterial bowel infections still predominated, affecting microbiology MLSOs, and with shigellosis topping the list. For the first time several shigella infections originated from quality control samples. The third typhoid infection of these surveys was reported. 
Table 5 Other infections

\begin{tabular}{|c|c|c|c|c|c|}
\hline Infecting organism & Year & Grade & Main discipline & Age & Sex \\
\hline $\begin{array}{l}\text { E coli and Klebsiella } \\
\text { E coli } \\
\text { Staphylococcus } \\
\text { Brucella melitensis }\end{array}$ & $\begin{array}{l}1989 \\
1989 \\
1989 \\
1988\end{array}$ & $\begin{array}{l}\text { Medical } \\
\text { MLSO } \\
\text { Secretary/receptionist } \\
\text { MLSO }\end{array}$ & $\begin{array}{l}\text { Morbid anatomy } \\
\text { Microbiology } \\
\text { Microbiology } \\
\text { Microbiology }\end{array}$ & $\frac{\overline{27}}{58}$ & $\begin{array}{l}\overline{\text { Female }}_{\text {Male }} \\
\overline{\text { M }}\end{array}$ \\
\hline
\end{tabular}

Table 6 Numbers of reporting laboratories and exposed staff in consecutive surveys

\begin{tabular}{llll}
\hline Survey period & Laboratories & Staff (person-years) & Ratio (staff laboratories) \\
\hline $1980-81$ & 260 & 34064 & 131 \\
$1982-83$ & 240 & 29223 & 122 \\
$1984-85$ & 193 & 23043 & 119 \\
$1986-87$ & 235 & 28524 & 121 \\
$1988-89$ & 166 & 21756 & 131 \\
\hline
\end{tabular}

Accidents were not noted in these cases, thus emphasising the importance of scrupulous care in this area of work.

Mortuary workers were again represented among the tuberculous cases, several of which had a doubtful association with work.

Viral hepatitis, the original target of these surveys, ${ }^{2}$ maintained the low incidence reached in the second half of the decade without any case reported in 1988-1989. A delayed report, however, was received of one case of non-A, non-B hepatitis in 1986 which involved a medical morbid anatomist without recognised laboratory exposure. Tests excluded hepatitis A and B as well as infection by Epstein-Barr virus, cytomegalovirus and leptospirosis, and the patient recovered completely. The occupational origin of most recently reported cases is doubtful. Unless specific prophylactic measures before and after exposure to hepatitis $B$ have been widely implemented, the current low incidence suggests improved working conditions and more meticulous techniques than in earlier years. If so, this should usefully lower the risks of exposure to other blood-borne agents such as human immunodeficiency virus, of which the incidence has been rising in the general population in recent years.

This survey was conducted with support from the Association of Clinical Pathologists and with the cooperation of the Institute of Medical Laboratory Scientists and the British Association in Forensic Medicine. We thank all those who provided information for the survey; also $\mathrm{Mr}$ W Smyth and Miss Fiona Johnston at the Communicable Diseases (Scotland) Unit for processing the data and typing the paper, respectively.

1 Grist NR. Hepatitis in clinical laboratories: a three-year survey. J Clin Pathol 1975;28:255-9.

2 Grist NR, Emslie JAN. Infections in British clinical laboratories, 1986-87. J Clin Pathol 1989;42:677-81. 